\title{
Adapting a community-participatory wildlife conservation model to management of Nigerian national parks for sustainable tourism
}

\author{
P. C. Ngoka $^{1} \&$ G. A. Lameed ${ }^{2}$ \\ ${ }^{I}$ Department of Hospitality and Tourism Management, \\ Michael Okpara University of Agriculture, Umudike, Nigeria \\ ${ }^{2}$ Department of Wildlife and Fisheries Management, \\ University of Ibadan, Nigeria
}

\begin{abstract}
Conservation areas, especially national parks, are the major tourism destinations of Sub-Saharan Africa, and wildlife constitutes the key attraction to the region. In Nigeria, the protection of wildlife for tourism is greatly hampered by the dominance of cultural attitudes toward wildlife utilization. The modern concept of protected areas came on board as an imposition from colonial authorities; that excluded the socio-cultural and economic systems of the local communities. People's attitudes to state-instituted wildlife programmes have continued to tilt toward suspicion and distrust, and sometimes outright opposition and conflicts have resulted. Community participation in state wildlife conservation programmes is known to have resolved socio-economic and political conflicts, and reduced illegal extraction of wildlife resouces to the barest minimum. This study surveyed 4 community-participatory wildlife management programmes in Botswana, Zambia, and Zimbabwe with a view to adapting them to the management of Nigerian National Parks for sustainable tourism. Surveys of the key features of the programmes were compared with current management practice in Nigeria. It was found that the kind of model in which certain share of management and staff composition, added to percentages of profits from conservation projects go to the host communities does not exist in Nigeria. Rather a model known as Support Zone Development programme (SZDP) is in use by the National Park Service (NPS); which allows limited involvement of support zone communities. A drive toward the community-participatory model was recommended as expedient to increase interest and support for state
\end{abstract}


conservation programmes in Nigeria, and ultimately encourage better development of tourism.

Keywords: local communities, co-management, natural resources, wildlife conservation, national parks, sustainable tourism, socio-economic empowerment, Nigeria.

\section{Introduction}

Forms and rates of natural resource exploitation are generally shaped by cultural, social and economic demands of the society (Ayodele [1]; Reo et al. [2]); while ecological factors set limits to how the processes of their renewal can be manipulated (Ayodele [1]). The conservation of living resources thus involves the rational use of resources among competing societal demands within the framework of ecological realities from which the resources are derived.

Across sub-Saharan Africa, natural resources remain central to rural people's livelihoods. Although native people possess and practice sustainable management of natural resources within their settings (Duning [3]; Akachuku [4] and Fabricius et al. [5]), growing populations and changing patterns of economic activities have of recent tended to overstretch and upset the natural balance of nature that used to exist in traditional settings (Maguba [6]). Increase in natural resource exploitation needed to implement development programmes and to meet the growing needs and aspirations of rising populations has put unbearable pressure on natural resources; against the backdrop of lagging knowledge and practice of sustainable natural resource management in many places (Dasman [7]; Crump [8]). FAO [9] reported that the rainforest of Nigeria will be depleted in less than 100 years in the face of the prevailing rate of encroachment on forest land; noting that forest was disappearing at a rate of over $250 \mathrm{~km}^{2}$ a year through various developmental activities. In the circumstance, the rational use of biological entities has become all the more fundamental to management of the ecosystems in which they occur.

Modern systems of natural resource conservation such as national parks, forest and game reserves were introduced into sub-Saharan Africa by colonial authorities; which excluded the existing socio-cultural and economic systems of the people, and has often remained highly centralised and conditioned by government policies of the colonial and post colonial eras (Ajayi [10]; Ayeni [11]; Reo et al. [2]). In many cases, the local people had lived and depended on the land and its resources for their livelihoods prior to the establishment of such reserves. Consequently, it would be difficult to convince local people that restricted protected area access has valuable benefits (Lameed [12]). People's attitudes to state-instituted wildlife programmes have continued to tilt toward suspicion and distrust, and sometimes outright opposition and conflicts have resulted.

During the past decades, there has been a shift from this predominantly centralised natural resource management model toward more devolved models known as Community-Based Natural Resource Management (CBNRM); which seeks to strengthen locally accountable institutions for natural resource 
management and utilisation by transferring authority over natural resources to local communities. CBNRM involves some degree of co-management of resources between central authorities, local governments, and local communities which share rights and responsibilities through diverse institutional arrangements. The various forms of CBNRM and their several locally specific adaptations have greatly diversified approaches to natural resources management in sub-Saharan Africa; which have also achieved notable ecological, economic, and institutional achievements in places where they have been tried. Variants of this model have been endeared in Namibia, Zimbabwe, Tanzania, Kenya, Cameroon, and Ghana; with prized direct and indirect benefits, including the proliferation of natural resource conservation schemes, recovery of key wildlife resources, collapse of illegal use of wildlife, and substantial reduction of conflicts over land and resource control (Reo et al. [2]).

The concept of national park relative to global and sub-Saharan African experience is novel to Nigeria (Maguba [6]). No form(s) of CBNRM currently exist in the management of national parks and other conservation arrangements. Rather, the State Control Natural Resources Management (SCNRM) approach, as introduced by the colonial authorities, is still the only mode of natural resources management.

The pressure of excessive hunting, overgrazing, logging, slash and burn agriculture, and the fall outs of the developmental activities of a nation with some 160 million people can be enormous. The impact of sustained loss of biological diversity and environmental degradation are already telling on the environment, manifesting in soil erosion / landslides, desert encroachment, pollution, climate change and so on, and are already undermining biological productivity and other sustainable human activities in every ecological zone of the country (Maguba [6]).

The need for the protection and proper management of the nation's natural environment through the establishment of protected areas both by legislation and tradition becomes compelling. This appears to have been recognized right from the pre-independence era; hence a number of game reserves, forest reserves, and sanctuaries had been established beginning with the Yankari Game Reserve in Northern Nigeria established in 1955 (National Park Service (NPS) [13]). These early reserves formed the springboards for today's national parks, numbering 8; established as representative samples of the various ecological zones of the country (Maguba [6]). These include Kainji Lake National Park, Yankari National Park, Chad Basin National Park, Cross River National Park, Gashaka Gumti National Park, Old Oyo National Park, Kamuku National Park, and Okomu National Park (NPS [13]). Five additional national parks are presently being considered for inclusion into the National Park System (National Parks Board [14]).

In the context of present emphasis on tourism development in Nigeria, and given the importance of National Parks in Africa's tourism (Eltringham), the search for a sustainable management model for Nigerian national parks becomes expedient. In the present study, 4 variants of the CBNRM model in 3 countries in Southern Africa and 2 Nigerian national parks - Yankari National 
Park (YNP) and Cross River National Park (CRNP) under the SCNRM model were studied with a view to adapting the former to the management of the later.

\section{Objectives of the study}

The following objectives guided this study:

1) Ascertaining the objectives of the two study models including their variants

2) Finding out the key features of the study models

3) Determining the effects which the study models may have produced on their respective host communities

4) Finding out the perceptions of the local communities about the existence of the conservation areas in their domains in Nigeria.

\section{Methodology}

The study applied the explorative research design; whereby the study models were observed to ascertain their major objectives, key features, effects on host communities, and perceptions of the Nigerian projects under the SCNRM by locals. The CBNRM model was deemed to be the ideal, which Nigeria's SCNRM model is expected to adapt to. Four variants of the CBNRM model in 3 countries in Southern Africa - the Game Harvesting Project (GHP) in Kedia, Botswana; the Luangwa Integrated Rural Development Project (LIRDP) in Zambia; the Administrative Management by Design (ADMADE) Programme in Zambia, and the Communal Area Management Programme for Indigenous Resources (CAMPFIRE) in Zimbabwe - were studied. The primary source of data for the CBNRM was based on participant observation by which each variant of the model was studied for 3 months between 1997 and 1998. Also, 2 Nigerian national selected from 2 major ecological and cultural settings - Yankari National Park (YNP); located in the savannah belt of pastoral, hunting, largely Muslim people of North-eastern Nigeria, and Cross River National Park (CRNP); in the equatorial rain forest zone inhabited by farming/gathering, lumbering and hunting Christian South-eastern people - were studied. The objectives and key features of the SCNRM were studied through records kept by the National Park Service (NPS). The effects of the projects on host communities and perceptions of the local people toward the existence of the parks were obtained using structured questionnaire and focussed group discussions with community leaders and individuals in randomly selected support zone communities. In YNP, 800 out of 7,934 adult citizens were randomly selected from 6 ramdomly selected communities out of the 28 support zone communities of the park. In CRNP, 1,600 respondents out of 15,615 adults were randomly selected from 6 of the 34 support zone communities of the park. The support zone communities were identified from NPS records and confirmed during field surveys. The objectives of the conservation projects, the key features of the models, and the effects of the projects on local communities as identified were 
reported; while the perceptions of the local people in the Nigerian projects were expressed as proportions of elicited responses.

\section{Results}

Table 1 shows that the objectives of all variants of the CBNRM model in Southern Africa lay emphasis on local peoples' participation in management and sharing of benefits.

Table 1: Objectives of the conservation projects in Southern Africa under the CBNRM model.

\begin{tabular}{|c|c|c|}
\hline Variant of CBRNM & \multicolumn{2}{|c|}{ Objectives } \\
\hline $\begin{array}{l}\text { Game Harvesting } \\
\text { Project (GHP) in } \\
\text { Kedia, Botswana }\end{array}$ & a) & $\begin{array}{l}\text { To establish game harvesting and craft } \\
\text { production as part of the economic } \\
\text { activities of rural dwellers. } \\
\text { Income generation and employment } \\
\text { creation adopting a low-input system } \\
\text { that can break even within a short time. } \\
\text { Plough back profits into improving the } \\
\text { living standards of local communities } \\
\text { living in the project area through } \\
\text { sustainable use of wildlife resources for } \\
\text { community development in the areas of } \\
\text { agriculture, wildlife conservation, water } \\
\text { resources management. }\end{array}$ \\
\hline $\begin{array}{l}\text { Luangwa Integrated } \\
\text { Rural Development } \\
\text { Project (LIRDP) in } \\
\text { Zambia }\end{array}$ & b) & $\begin{array}{l}\text { To coordinate government and non- } \\
\text { government activities in the Luangwa } \\
\text { Valley in issues related to land and } \\
\text { resource use } \\
\text { As in GHP (b) and (c) }\end{array}$ \\
\hline $\begin{array}{l}\text { Administrative } \\
\text { Management by } \\
\text { Design (ADMADE) } \\
\text { in Zambia }\end{array}$ & a) & $\begin{array}{l}\text { To build conservation into national } \\
\text { planning priorities. } \\
\text { As in GHP (b) and (c) }\end{array}$ \\
\hline $\begin{array}{c}\text { Communal Area } \\
\text { Management } \\
\text { Programme for } \\
\text { Indigenous Resources } \\
\text { (CAMPFIRE) in } \\
\text { Zimbabwe } \\
\end{array}$ & b) & $\begin{array}{l}\text { To give power and authority to capable } \\
\text { local authorities to manage the natural } \\
\text { resources in their domain. } \\
\text { As in GHP (b) and (c). }\end{array}$ \\
\hline
\end{tabular}


Table 2 shows that Nigeria's SCNRM model did not provide for local people either in the management of the reserves, or sharing of benefits in their statement of objectives.

Table 2: Objectives of the national parks in Nigeria under the SCNRM management model.

\begin{tabular}{|c|c|}
\hline $\begin{array}{c}\text { National } \\
\text { Park/Project }\end{array}$ & Objectives \\
\hline $\begin{array}{c}\text { Yankari } \\
\text { National Park } \\
\text { (YNP) }\end{array}$ & $\begin{array}{l}\text { 1) To conserve and protect a representative } \\
\text { sample of wildlife - rich Sahel savannah } \\
\text { ecosystem in North-eastern Nigeria - under } \\
\text { the conventional model of total non- } \\
\text { interference by man. } \\
\text { 2) To provide opportunities for recreation. }\end{array}$ \\
\hline $\begin{array}{c}\text { Cross River } \\
\text { National Park } \\
\text { (CRNP) }\end{array}$ & $\begin{array}{l}\text { 1) To conserve and protect a biodiversity- } \\
\text { rich, relatively intact largest moist } \\
\text { forest in the equatorial rainforest } \\
\text { ecological zone from increasing threat } \\
\text { to its integrity from uncontrolled } \\
\text { farming/gathering, logging, and hunting } \\
\text { 2) To capture revenue from tourism. }\end{array}$ \\
\hline
\end{tabular}

Tables 3(a) and (b) shows that all variants of the CBNRM model featured substantial involvement of local people in their management as well as provided for stipulated share of benefits by local people.

Table 4 indicates that in the Nigerian SCNRM model, all operations are centralised at the level of the Federal Government. Any involvement or direct benefits to the natives are at Government discretion.

Table 5 shows that local people are empowered to derive substantial benefits from the conservation projects, added to sustainable management of natural resources under the CBNRM model while the SCNRM model is still saddled with several community-emanating problems that are capable of threatening the integrity of the parks and ultimately tourism development in spite of support zone projects.

Table 6 shows that the substantial proportion of the local people would welcome the idea of Nigerian national parks. 
Table 3: (a) Key features of the CBNRM model in Southern Africa.

\begin{tabular}{|c|c|c|c|}
\hline $\begin{array}{l}\text { Variant } \\
\text { of } \\
\text { CBNRM }\end{array}$ & $\begin{array}{l}\text { Political and Administrative } \\
\text { Framework }\end{array}$ & $\begin{array}{l}\text { Sharing of } \\
\text { Responsibilities }\end{array}$ & $\begin{array}{l}\text { Sharing of } \\
\text { Benefits }\end{array}$ \\
\hline GHP & $\begin{array}{l}\text { Three levels of administration } \\
\text { exist: (a) The Remote Area } \\
\text { Dwellers (RADs)-composed of } \\
\text { people who live in the wildlife } \\
\text { areas and whom the wildlife } \\
\text { utilization programmes are } \\
\text { mostly meant to benefit.(b) The } \\
\text { Village Development } \\
\text { Committees (VDCs) made up } \\
\text { of local committees at the } \\
\text { wildlife resources base. } \\
\text { (c) District Councils (DCs). }\end{array}$ & $\begin{array}{l}\text { The RADs are the } \\
\text { primary executors of } \\
\text { the wildlife utilization } \\
\text { projects sited within } \\
\text { their communities } \\
\text { especially the game } \\
\text { harvesting and tannery } \\
\text { projects. The VDCs } \\
\text { and the DCs perform } \\
\text { administrative and } \\
\text { technical functions } \\
\text { including assisting the } \\
\text { Department of Wildlife } \\
\text { and National Parks in } \\
\text { determining the quota } \\
\text { of each species to be } \\
\text { harvested each year; } \\
\text { issuance of hunting } \\
\text { licences to delegated } \\
\text { hunters of the RADs, } \\
\text { and provision of } \\
\text { vehicles and guns. }\end{array}$ & $\begin{array}{l}70 \% \text { of annual } \\
\text { total revenue } \\
\text { goes to RADs } \\
\text { bank account. It } \\
\text { is at the complete } \\
\text { discretion of the } \\
\text { communities to } \\
\text { decide what to } \\
\text { do with their } \\
\text { share or how to } \\
\text { go about it. }\end{array}$ \\
\hline LIRDP & $\begin{array}{l}\text { a) The LIRDP is ultimately } \\
\text { responsible to the President. (b) } \\
\text { An Aadvisory Committee (AC). } \\
\text { (c) The Local Leaders } \\
\text { subcommittee (LLD) of the AC } \\
\text { consisting of } 6 \text { chiefs of the } \\
\text { Mangwe sub district, the } 4 \text { ward } \\
\text { chairmen, the member of } \\
\text { parliament for Malambo } \\
\text { constituency, the Senior } \\
\text { Administrative Officer of } \\
\text { Mamgwe sub-service and the } \\
\text { Save the Children Federation. } \\
\text { a) The LIRDP is ultimately } \\
\text { responsible to the President. (b) } \\
\text { An Aadvisory Committee (AC). } \\
\text { (c) The Local Leaders } \\
\text { subcommittee (LLD) of the AC } \\
\text { consisting of } 6 \text { chiefs of the } \\
\text { Mangwe sub district, the } 4 \text { ward } \\
\text { chairmen, the member of } \\
\text { parliament for Malambo } \\
\text { constituency, the Senior } \\
\text { Administrative Officer of } \\
\text { Mamgwe sub-service and the } \\
\text { Save the Children Federation. }\end{array}$ & 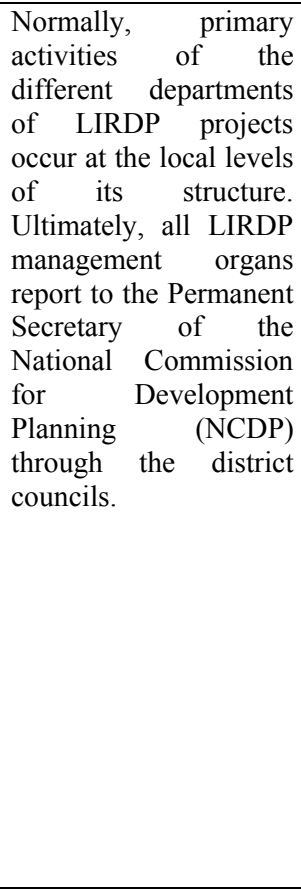 & $\begin{array}{l}40 \% \text { of derived } \\
\text { revenue goes to } \\
\text { the communities } \\
\text { Disbursement of } \\
\text { this revenue is } \\
\text { entirely at the } \\
\text { discretion of the } \\
\text { collective } \\
\text { decision of the } \\
\text { people through } \\
\text { the local leaders } \\
\text { committee. (b) } \\
60 \% \text { is retained } \\
\text { by Government } \\
\text { for the running } \\
\text { cost and } \\
\text { management of } \\
\text { the project. }\end{array}$ \\
\hline
\end{tabular}


Table 3: (b) Key features of the CBNRM model in Southern Africa continued.

\begin{tabular}{|c|c|c|c|}
\hline $\begin{array}{l}\text { Variant of } \\
\text { CBNRM }\end{array}$ & $\begin{array}{l}\text { Political and } \\
\text { Administrative } \\
\text { Framework }\end{array}$ & Sharing of Responsibilities & Sharing of Benefits \\
\hline ADMADE & $\begin{array}{l}\text { The programme is } \\
\text { broken into units called } \\
\text { Game Management } \\
\text { Areas (GMAs) Each } \\
\text { GMA has a local policy- } \\
\text { making body consisting } \\
\text { of the ruling chiefs, the } \\
\text { locally elected ward } \\
\text { chairman, the area's } \\
\text { member of parliament, } \\
\text { the District Governor, } \\
\text { the District Political } \\
\text { Secretary, and the } \\
\text { appropriate wildlife } \\
\text { officers of the area } \\
\text { including the Wildlife } \\
\text { Warden for the particular } \\
\text { province. }\end{array}$ & $\begin{array}{l}\text { The execution of the projects } \\
\text { of ADMADE occurs at the } \\
\text { local villages, coordinated } \\
\text { directly by the GMA } \\
\text { management arrangement. } \\
\text { The GMAs adopt an annual } \\
\text { programme of wildlife } \\
\text { management as } \\
\text { recommended by the unit } \\
\text { leader, and approves annual } \\
\text { budgets for community } \\
\text { development projects. }\end{array}$ & $\begin{array}{l}40 \% \text { of annual yield } \\
\text { goes to the } \\
\text { generating } \\
\text { ADMADE unit for } \\
\text { meeting the unit's } \\
\text { management cost. } \\
35 \% \text { is for financing } \\
\text { local community } \\
\text { development } \\
\text { projects; } 15 \% \text { goes } \\
\text { to the Department of } \\
\text { National Parks and } \\
\text { Wildlife Services } \\
\text { (DNPWS) for } \\
\text { supporting } \\
\text { ADMADE } \\
\text { programmes. Finally } \\
10 \% \text { goes to the } \\
\text { Zambia National } \\
\text { Tourist Board } \\
\text { (ZNTB) for the } \\
\text { promotion } \\
\text { tourism in the } \\
\text { country. }\end{array}$ \\
\hline$\overline{\mathrm{CAl}}$ & $\begin{array}{l}\text { (a) Authorised district } \\
\text { councils form the } \\
\text { administrative units of } \\
\text { CAMPFIRE. } \\
\text { Nyaminnyami District } \\
\text { Council typifies the } \\
\text { administrative units. A } \\
\text { body known as } \\
\text { Nyaminnyami Wildlife } \\
\text { Management Trust } \\
\text { provides for members at } \\
\text { the grass root level. 13 } \\
\text { Ward Councillors' } \\
\text { represent the rural } \\
\text { communities; (b) } \\
\text { Officials of the Ministry } \\
\text { of Wildlife Resources. }\end{array}$ & $\begin{array}{l}\text { CAMPFIRE's origin stems } \\
\text { from the National Parks and } \\
\text { Wildlife Act of } 1975 \text { which } \\
\text { stipulates that local } \\
\text { authorities who satisfy the } \\
\text { Department of National } \\
\text { Parks that they can manage } \\
\text { the natural resources in their } \\
\text { own domain should be } \\
\text { accorded the power to do so. } \\
\text { Primary operations such as } \\
\text { game harvesting, processing } \\
\text { and craft works occur at the } \\
\text { local villages; under the } \\
\text { supervision of the district } \\
\text { council management team. } \\
\text { Officials of the Ministry of } \\
\text { Wildlife Resources represent } \\
\text { Government interest and } \\
\text { perform technical functions } \\
\text { in the administration of } \\
\text { CAMPFIRE. }\end{array}$ & $\begin{array}{l}60 \% \text { of proceeds go } \\
\text { to the local } \\
\text { communities } \\
\text { through the district } \\
\text { councils. The local } \\
\text { communities decide } \\
\text { what to do with their } \\
\text { share. } 40 \% \text { goes to } \\
\text { the the government } \\
\text { through the Ministry } \\
\text { of Wildlife } \\
\text { Resources. }\end{array}$ \\
\hline
\end{tabular}


Table 4: Key differences in features between the CBNRM model and the SCNRM model.

\begin{tabular}{|c|c|c|c|}
\hline Model & $\begin{array}{l}\text { Administrative } \\
\text { framework }\end{array}$ & $\begin{array}{c}\text { Sharing of } \\
\text { Responsibilities }\end{array}$ & $\begin{array}{l}\text { Sharing of } \\
\text { Benefits }\end{array}$ \\
\hline CBNRM & $\begin{array}{l}\text { Is essentially } \\
\text { community- } \\
\text { based; empowers } \\
\text { local people to be } \\
\text { able to shape their } \\
\text { own destinies } \\
\text { through decide on } \\
\text { issues that } \\
\text { concern them. }\end{array}$ & $\begin{array}{l}\text { There exists a } \\
\text { co-management } \\
\text { structure which } \\
\text { stipulates } \\
\text { sustantial } \\
\text { involvement of } \\
\text { local people. }\end{array}$ & $\begin{array}{l}\text { Provides for agreed } \\
\text { share of proceeds from } \\
\text { the projects going to } \\
\text { local people for } \\
\text { community } \\
\text { development and } \\
\text { improvement of living } \\
\text { standard. }\end{array}$ \\
\hline SCNRM & $\begin{array}{l}\text { Nigeria operates a } \\
\text { national park } \\
\text { system in which } \\
\text { all national parks } \\
\text { are administered } \\
\text { by the Federal } \\
\text { Government } \\
\text { through the } \\
\text { National Park } \\
\text { Service (NPS). } \\
\text { The Conservator } \\
\text { General (CG) is } \\
\text { the chief } \\
\text { executive of the } \\
\text { NPS. Each park is } \\
\text { administered by a } \\
\text { Director General } \\
\text { who reports to the } \\
\text { CG. The CG is } \\
\text { accountable to the } \\
\text { Permanent } \\
\text { Secretary of the } \\
\text { Federal Ministry } \\
\text { of Environment. }\end{array}$ & $\begin{array}{c}\text { The } \\
\text { administration } \\
\text { of national } \\
\text { parks is } \\
\text { centrally } \\
\text { executed by the } \\
\text { Federal } \\
\text { Government, } \\
\text { with minimal } \\
\text { involvement of } \\
\text { the local } \\
\text { communities. }\end{array}$ & $\begin{array}{l}\text { There is no extraction } \\
\text { of natural/wildlife } \\
\text { resources whatsoever- } \\
\text { timber or wildlife } \\
\text { products. Sharing } \\
\text { arrangement for direct } \\
\text { tangible benefits does } \\
\text { not exist. Meagre } \\
\text { amounts generated } \\
\text { from recreation go } \\
\text { entirely to the NPS. } \\
\text { *89\% of the jobs go to } \\
\text { the support zone } \\
\text { communities. } \\
\text { *NPS assists support } \\
\text { zone communities in } \\
\text { community } \\
\text { development through } \\
\text { support zone projects - } \\
\text { rural electrification, } \\
\text { water resources mgt., } \\
\text { and health facilities and } \\
\text { equipment. }\end{array}$ \\
\hline
\end{tabular}

*Government discretion 
Table 5: $\quad$ Benefits / effects of CBNRM on host communities.

\begin{tabular}{|c|c|}
\hline CBNRM Model & SCNRM Model \\
\hline $\begin{array}{l}\text { (a) Marketable items in the } \\
\text { forms of meat, skins and } \\
\text { trophies. (b) Job opportunities } \\
\text { are created at the various levels } \\
\text { of the project operations, } \\
\text { especially local who would have } \\
\text { otherwise taken to poaching. (c) } \\
\text { Drastic reduction of illegal } \\
\text { extraction of wildlife resources. }\end{array}$ & $\begin{array}{l}\text { Support zone projects to local } \\
\text { communities. Illegal extraction of wildlife } \\
\text { resources has been heavy. Rampant } \\
\text { encroachment of grazing and wild fires by } \\
\text { locals. Local agitations against the } \\
\text { national park system led to Bauchi (home) } \\
\text { state take over and stripping of the park } \\
\text { from the national park system in 2006; } \\
\text { reverting the park to its original status as a } \\
\text { game reserve. }\end{array}$ \\
\hline
\end{tabular}

Table 6: Local people's perceptions and wishes for the existence of national parks under the CBNRM and the SCNRM models.

\begin{tabular}{|c|c|c|c|c|}
\hline \multirow{2}{*}{ Perceptions / Wishes } & \multicolumn{2}{|c|}{ CBNRM Model } & \multicolumn{2}{|c|}{ SCNRM Model } \\
\hline & $\mathrm{F}$ & $\%$ & $\mathrm{~F}$ & $\%$ \\
\hline Sustain the SCNRM Model & 50 & 6 & 50 & 6 \\
\hline $\begin{array}{c}\text { Stay in the national park } \\
\text { system but incorporate local } \\
\text { people in decision-making and } \\
\text { management }\end{array}$ & 460 & 58 & 962 & 58 \\
\hline $\begin{array}{l}\text { Relinquish the Park to state / } \\
\text { local Governments }\end{array}$ & 245 & 31 & 286 & 31 \\
\hline \multirow[t]{2}{*}{$\begin{array}{l}\text { Hand over park to local } \\
\text { communities }\end{array}$} & 43 & 5 & 90 & 5 \\
\hline & 800 & 100 & 1600 & 100 \\
\hline
\end{tabular}

\section{Discussion}

From table 1, it was deduced that the objectives of all the variants of the CBNRM model in Southern Africa possess one thing in common - focus on local people. The projects are designed to achieve empowerment of the local people through self determined and self-supporting productivity which lean on self reliant community-based management of natural resources on a sustainable basis. They are all designed to, and to redistribute the benefits in favour of rural populations of the project areas. On the contrary, Nigeria's SCNRM model 
(table 2), though well-intentioned for biodiversity conservation, amelioration of climate, and creation of opportunities for recreation, has no mention of local people, either in the management of the reserves, or sharing of benefits in their statement of objectives. Any benefits to local people by way of employment and support zone projects are at government discretion.

The Nigerian SCNRM model has been perceived by local people as denying them access to traditional uses - hunting, farming/gathering, and logging; as well as modern commercial uses - resource harvesting, proceeds from tourism - of what was once their land and key source of livelihoods. Expectedly, such a situation would be fraught with tension as already being experienced in some Nigerian National Parks such as YNP. The turbulence generated by the current SCNRM approach does not created a congenial atmosphere for sustainable tourism development. Firstly, the environment has been prone to destabilisation through illegal activities in the reserve areas such as poaching, illegal encroachment of cropping, logging, and grazing activities. Further, these activities destroy the natural resources and ecosystems which form the attractions that give essence to tourism. On the other hand, the CBNRM model in Southern Africa that allows for direct participation of local people has been able to eliminate suspicion and established a harmony between the people and their natural resources. This has led to ecological balance through sustained manipulation of the environment for controlled traditional and commercial uses; thereby has been able to empower local people to take charge of their own destinies through the ability to add value to their natural resources on a sustainable yield basis.

The CBNRM approach is better disposed to create a conducive environment for tourism to thrive in their domain. It has also better encouraged the needed political and social atmosphere, along with the right images for tourism development; hence the better development of tourism in the region relative to Nigeria (Ayeni [11]). In essence, it will be hard to effect sustainable management of natural resources without the cooperation of the local people (Duning [3]).

However, it might be unrealistic to expect early tangible benefits from the CBNRM in the Nigerian setting for three reasons:

1) Ecological differences in the study locations - West African, and Southern African settings. Wildlife populations are sparse in the former which consequently witnessed greater forcus on the forestry sector from the outset, while wildlife conservation was the emphasis in the later (Ajayi [10]).

2) The extraction of wildlife resources as obtains in the Southern African setting might not substantially apply in Nigeria because not much exist for extraction (FAO [9]; Ayeni [11]).

3) Long period of devastation of the original natural setting due to developmental pressure on natural resources and inefficient management (Ajayi [10]; Ayeni [11]).

Accordingly, long period of patience and appropriate management would be necessary for vital wildlife species to recover. In this context, managing the 
parks, targeting ultimate sustainable tourism development should be the logical focus.

\section{Conclusion}

From the outcome of this study, it can be concluded that alienating local people from direct involvement in the management of Nigerian national parks has been, and might remain antithetical to sustainable management of the parks for sustainable tourism. Forms of co-management of natural resources in which responsibilities and benefits are shared between Government and support zone communities appear inevitable if the environment is to be saved, and for national parks to make significant impact on locals in the forms of direct benefits. Such a situation can resolve conflicts, garantee local support for protection of the parks, and create the right environment for tourism to thrive.

\section{Recommendations}

Appropriate variants of CBNRM are expedient for sustainable tourism development in Nigeria. Engaging the local people in meaningful dialogue can reveal the most convenient structure to be adopted in each local setting. For instance, in the Northern setting (typified by YNP) where local community leaders exert considerable influence and control over their subjects, local leaders, as may be agreed, might represent their people on the board and management of parks. On the other hand, in the Southern environment (such as CRNP) where the people are less submissive to local rulers, outright election of representatives might be necessary.

\section{References}

[1] Ayodele, I.A., An eclological basis for the management of Old Oyo Nationl Park, Unpublished Ph.D. thesis submited to the Department of Wildlife and Fisheries Management, University of Ibadan, 1988.

[2] Reo, D, Nelson, F and Sandbrook, C. (eds) Community Management of Natural Resources in Africa - Impacts, Experiences and Future Directions. Natural resources Issue No. 18, International Institute for Environment and Development: London, pp. 1-4; 55-94, 2009.

[3] Duning, A.T., Guardians of the Land: Indigenous People and the Health of the Earth" World Watch Paper, 112, 1992.

[4] Akachukwu, A.E., Prospects and constraits of biodiversity conservation in South-eastern Nigeria. (Chapter 13). Implementing the Biodiversity Conservation: Nigeria and African Perspectives, (eds.) Aya, I.A. and Ajayi, O., Nigerian Institute of Advanced Legal Studies: Lagos, pp. 138-152, 2000.

[5] Fabricius, C., cited in Reo, D; Nelson, F and Sandbrook, C., eds. Community Management of Natural Resources in Africa - Impacts, 
Experiences and Future Directions. Natural resources Issue No. 18, International Institute for Environment and Development: London, pp. 5, 2009.

[6] Maguba, L.B., National parks and their benefits to local cmmunities in Nigeria, Nigeria National Park Service: Lagos, pp. 1- 48, 2002.

[7] Dasmann, R.F. Wildlife Ecology. John Wiley and Sons Ltd: London, pp. 252, 1981.

[8] Crump, M. A. (1991): Dictionary of Environment and Development, London: Earths Can Pub. Ltd.

[9] FAO, Forest development in Nigeria: project findings and recommendations. FO:DP/NIR/71/546 terminal report, FAO:Rome, pp. 88, 1979.

[10] Ajayi, S.S., Utilization of forest wildlife in West Africa. F.A.O. Rome F.O. Misc/79/26:76. Pp. 15-36, 1979.

[11] Ayeni, J. S. O., Wildlife resources conservation and management in Nigeria. Proceedings of the UNESCO-MAB regional training workshop on biodiversity and conservation, Akure, Nigeria. 23-26 July, UNESCODakar/MAB National Committee-Nigeria: Akure, pp. 135-139, 1995.

[12] Lameed, G.A., Ecological considerations for the management of endangered primate species in Cross River National Park: implications for e Lameed, G.A., Unpublished Ph.D. thesis submitted to the Department of Wildlife and Fisheries Management, University of Ibadan, 1999.

[13] National Park Service, Nigeria National Parks Profile, Nigeria National Parks; National Park Service: Abuja, pp. 3-8, 2000.

[14] National Parks Board, Synopsis on the parks, Nigerian National Parks; National Parks Service: Abuja, pp. 1-5, 1995. 